\title{
ST Elevasyonsuz Miyokart Enfarktüsü Geçiren Erkek Hastalarda Serbest Testosteron Düzeyi ile Koroner Arter Hastalığının Ciddiyeti Arasındaki İlişki
}

\section{The Relationship Between Free Testosterone Level and The Severity of Coronary Artery Disease in Male Patients with Non-ST Elevated Myocardial Infarction}

\author{
Diyar KÖPRÜLÜ $^{1}{ }^{(\mathbb{D})}$, Mustafa Begenç TAŞCANOV 2
}

1 Ordu Devlet Hastanesi, Kardiyoloji Bölümü, Ordu, Türkiye

2 Harran Üniversitesi Tıp Fakültesi Kardiyoloji Anabilim Dalı, Şanlıurfa, Türkiye

Öz.

Amaç: Syntax (SYNergy between PCI with TAXUS and Cardiac Surgery) skoru (SS) Koroner arter hastalığının (KAH) ciddiyetini belirlemede kullanılan bir skorlama sistemidir. Yüksek SS ve düşük testosteron düzeyi koroner arter haslığı olan hastalarda istenmeyen kardiyak olaylar ile ilişkili bulunmuştur. Bu çalışmada ST yükselmesi olmayan miyokart enfarktüsü (NSTEMI) geçiren erkek hastalarda serbest testosteron ile SS arasındaki ilişkiyi araştırmayı amaçladık.

Materyal ve Metod: Bu çalışmaya, NSTEMI tanısıyla koroner anjiyografi yapılan 98 erkek hasta dâhil edildi. Hastalar SS değerlerine göre 2 gruba ayrıldı: Grup 1 SS $<22$ olan hastalar, grup 2 ise SS $\geqslant 22$ olan hastalar olarak tanımlandı. Her iki grup, bazal karakteristik özellikler ve serum serbest testosteron düzeyleri karşılaştııldı. Bulgular: Grup 1 hastalar ile karşılaştııldıklarında, grup 2'deki hastalarda total testosteron (32 \pm 23 'e karşın 23 $\pm 17 ; P=0.032$ ) ve serbest testosteron (10 [4 -16]) 'e karşın 8 [4-12], $P=0.011)$ düzeyi anlamlı olarak daha düşük tespit edildi. Korelasyon analizinde SS ile total testosteron $(r=-0.480, p=0.001)$ ve serbest testosteron $(r=$ $0.733, p=0.001$ ) düzeyleri arasında negatif korelasyon olduğu saptandı. Çok değişkenli lojistik regresyon analizinde serbest testosteron (odds oranı: 0.906; \%95 güven aralığl: 0.838-0.980; $P=0.014$ ) yüksek SS'nu etkileyen bağımsız bir belirleyici olarak tespit edildi.

Sonuç: NSTEMI geçiren erkek hastalarda düşük serbest testosteron düzeyi bağımsız olarak yüksek SS ile ilişkilidir.

Anahtar Kelimeler: Syntax skoru, ST elevasyonsuz miyokart infaktüsü, Serbest testosteron

Abstract

Background: Syntax (SYNergy between PCI with TAXUS and Cardiac Surgery) score (SS) is an angiographic scoring system for determining the severity of coronary artery disease (CAD). High SS and low testosterone levels have found to be associated with poor cardiac events in patients with CAD. In this study, we aimed to investigate the relationship between free testosterone level and SS in male patients with Non ST-Elevation Myocardial Infarction (NSTEMI).

Materials and Methods: The study included 98 male patients with NSTEMI undergoing coronary angiography. Patients were divided into two groups according to the SS values: group 1 defined as patients with SS $<22$, while group 2 was defined as patients with $S S \geqslant 22$. Two groups were compared in terms of baseline characteristics and serum free testosterone level.

Results: When compared with group 1, patients in group 2 had significantly lower levels of total testosterone (32 \pm 23 vs. $23 \pm 17 ; P=0.032)$ and free testosterone $(10[4-16])$ vs. $8[4-12] P=0.011)$. In correlation analysis, SS was negatively correlated with total testosterone $(r=-0.480, p=0.001)$ and free testosterone level $(r=-0.733, p$ $=0.001$ ). Multivariate logistic regression analysis demonstrated that free testosterone was an independent predictor of high SS (odds ratio: $0.906 ; 95 \%$ confidence interval: $0.838-0.980, P=0.014$ ).

Conclusions: Low free testosterone level is independently associated with high SS in male patients with NSTEMI.

Key words: Syntax score, Non ST-Elevation myocardial infarction, Free testestorone,
Sorumlu Yazar I

Corresponding Author

Dr. Diyar KÖPRÜLÜ

Ordu Devlet Hastanesi, Kardiyoloji Bölümü, Ordu/Türkiye

Tlf: 04522343232

e- mail: drkoprulu12@icloud.com

Geliş tarihi / Received:

08.01.2020

Kabul tarihi / Accepted:

09.03.2020

DOI: $10.35440 /$ hutfd. 671941 


\section{Giriş}

Dünya genelinde, en önemli morbidite ve mortalite nedeni olan koroner arter hastalığı (KAH), kardiyovasküler hastalıklardan önemli sağlık sorunlarından biri olmaya devam etmektedir. Erkekler bilinen risk faktörlerinin önceden önlenmesine rağmen, kadınlara kıyasla 2 kat daha fazla $\mathrm{KAH}$ geliştirme olasılığına sahiptir (1). Kadınlardaki daha düşük KAH olasılığı, büyük ölçüde endojen östrojenlerin kardiyoprotektif rolüne bağlanmıştır. Aynı şekilde, testosteronun erkeklerde kardiyovasküler sistem için koruyucu bir rol oynadığı da gösterilmiştir (2-3).

Testosteronun ateroskleroza aracılık eden kardiyovasküler risk faktörleri olan kolesterol, endotel disfonksiyonu ve inflamasyon üzerinde yararlı etkileri vardır. Hayvan deneyi çalışmalarında, testosteronun ateroprotektif olduğu ve eksikliğinde prematür aterogenezisin uyarıldığı gösterilmiştir. Ayrıca, düşük testosteron düzeyinin istenmeyen kardiyak olaylar ile ilişkili olduğu da bildirilmiştir (4-6). Serbest hormon hipotezine göre, serbest testosteron dokulara erişimi olan total testosteronun biyolojik olarak aktif fraksiyonudur (7).

Syntax (SYNergy between PCI with TAXUS and Cardiac Surgery) skoru (SS) KAH'ın ciddiyetini ve yaygınlığını değerlendirmek için kullanılan anjiyografik bir skorlama sistemi olarak kullanılmaktadır (8). Yüksek SS'nun istenmeyen kardiyak olaylar ile ilişkili olduğu gösterilmiştir (9). Literatürde ST yükselmesi olmayan miyokart enfarktüsü (NSTEMI) ile başvuran erkek hastalarda, serbest testosteron düzeyi ile SS arasındaki ilişkiyi inceleyen çalışmalar sinırlıdır.

Bu çalışmadaki amacımız, NSTEMı ile başvuran erkek hastalarda KAH'ın ciddiyeti ve yaygınlığının göstergesi olan SS ile serbest testosteron düzeyi arasındaki ilişkiyi incelemektir.

\section{Materyal ve Metod Çalışma popülasyonu}

Bu çalışmaya NSTEMI tanısıyla koroner anjiografi yapılan 98 erkek hasta dâhil edildi. Daha önce bilinen KAH, ciddi kalp kapağı hastalığı, kalp yetmezliği, malignite, akut enfeksiyon, antiandrojen tedavi alan, ciddi karaciğer hastalığı ve böbrek yetmezliği olan hastalar çalışma dışı bırakıldı. Tip 2 diyabetes mellitus, açlık kan şekeri seviyesi $\geq 126$ $\mathrm{mg} / \mathrm{dL}$ ve/veya hastanın daha önce diyabet tanısı alınması ve tedavi edilmesi olarak tanımlandı. Sistolik kan basıncının $\geq 140 \mathrm{mmHg}$ ve/veya diyastolik kan basıncının $\geq$ $90 \mathrm{mmHg}$ olması ya da antihipertansif tedavi kullanıyor olmak ve/veya bilinen hipertansiyona sahip olmak hipertansiyon olarak tanımlandı. Çalışma Harran Üniversitesi Tıp Fakültesi etik kurul tarafından onaylandı (Etik kurul tarih: 09/09/2019; karar no: 19/10/12) ve Helsinki Bildirgesi'nin kurallarına uygun olarak uygulandı. Tüm hastalardan bilgilendirilmiş onam alındı.

\section{Biyokimyasal analiz}

En az sekiz saatlik bir açlık sonrası sabah venöz kan örnekleri alındı ve standart laboratuvar yöntemleri kullanılarak analiz edildi. Ek olarak, serum serbest testosteron düzeyinin çalışıması amacıyla da biyokimya tüpüne venöz kan örneği alındı. Örnekler, 4000 rpm'de 15 dakika santrifüj edildi ve serum analiz gününe kadara $-80^{\circ} \mathrm{C}$ 'de saklandı. Daha sonra, tüm katılımcıların serbest testosteron seviyeleri aynı anda ve aynı serum örnekleriyle çalışıldı. Serum serbest testosteron enzim bağlı immünosorbent deneyi (ELISA) ile ölçüldü.

\section{Koroner anjiyografi}

Hastalara radiyal veya femoral yolla Judkins tekniği ile koroner anjiyografi yapıldı. Tüm anjiyografik görüntüler iki bağımsız kardiyolog tarafından değerlendirilmiştir. KAH'nın anatomik yaygınlığı ve ciddiyeti http://www.syntaxscore.com adresinden indirilen versiyon kullanılarak hesaplanıldı. Hastalar SS'na göre hastalar iki gruba bölündü: grup 1 (SS <22 olanlar, hafif KAH) ve grup 2 (SS $\geq 22$ olanlar, ciddi KAH).

\section{İstatistiksel analiz}

Tüm istatistiksel hesaplamalar için Sosyal Bilimler İçin İstatistik Programı 20 (IBM SPSS, Chicago, IL, USA) kullanıldı. Verilerin normal dağııımını test etmek için Kolmogorov-Smirnov testi kullanıldı. Sürekli değişkenler ortalama \pm SD veya median (interquartile range) olarak ifade edildi ve dağılıma göre Student t veya Mann-Whitney $U$ testleri ile karşılaştırıldı. Kategorik değişkenler yüzde ve sayı olarak ifade edildi ve Ki-kare testi ile karşıllaştırıldı. SS'nun diğer sürekli değişkenlerle korelasyonunu belirlemek için Sperman korelasyon analizi yapıldı. Ayrıca, SS'nun bağımsız prediktörlerini belirlemek için çok değişkenli lojistik regresyon analizi yapıldı. İstatistiksel anlamlıık düzeyi $p<0.05$ olarak kabul edildi.

\section{Bulgular}

Çalışma popülâsyonunun klinik özellikleri Tablo 1'de verilmiştir. Yaş, diyabet, hipertansiyon, vücut kitle indeksi ve sigara açısından gruplar arasında anlamlı fark yoktu (hepsi için $P>0.05)$. Ancak grup 1'deki hastalar ile karşılaştırıdıklarında, grup 2'deki hastalarda total kolesterol (177 [144 -177] 'e karşın 198 [169-227], $P=0.038$ ), düşük dansiteli kolesterol (106 [74-130] 'e karşın 124 [98.5-156.5], $P=$ 0.025) ve C-reaktif protein (11.9 [6.3-33.7] 'e karşın 27.5 [10.4-67.3], $P=0.048)$ anlamlı olarak daha yüksek idi. Buna karşın, grup 2 hastalarda total testosteron (32 $\pm 23^{\prime} \mathrm{e}$ karşın $23 \pm 17 ; P=0.032$ ) ve serbest testosteron (10 [4 16]) 'e karşın 8 [4-12], $P=0.011$ ) düzeyi ise grup 2 hastalarda anlamlı olarak daha düşük olarak saptandı. Yapılan korelasyon analizinde SS ile total testosteron $(r=-0.480, p$ $=0.001)$ ve serbest testosteron $(r=-0.733, p=0.001)$ arasında negatif yönde bir korelasyon olduğu görüldü (Şekil 1). Ek olarak, SS ile total kolesterol $(r=0.239, p=0.018)$ ve düşük dansiteli lipoprotein $(r=0.286, p=0.004)$ arasında 
da pozitif yönde zayıf bir korelasyon mevcuttu (Tablo 2).

Tablo. 1. Çalışmaya alınan hastaların temel karakteristik ve biyokimyasal özelliklerinin karşılaştırıması

\begin{tabular}{|c|c|c|c|}
\hline Değişkenler & $\begin{array}{l}\text { Grup 1 } \\
(n=57)\end{array}$ & $\begin{array}{l}\text { Grup 2 } \\
(n=41)\end{array}$ & $\mathbf{P}$ \\
\hline Yaş & $58 \pm 11$ & $56 \pm 10$ & 0.962 \\
\hline Vücut kitle indexi (kg/m2) & $25 \pm 5$ & $24 \pm 3$ & 0.910 \\
\hline Hipertansiyon (\%) & $21(37)$ & $22(54)$ & 0.100 \\
\hline Hiperlipidemi (\%) & $21(37)$ & $15(37)$ & 0.979 \\
\hline Sigara (\%) & $21(46)$ & $16(39)$ & 0.518 \\
\hline Diyabetes mellitus (\%) & $13(23)$ & $11(27)$ & 0.650 \\
\hline $\mathrm{EF}(\%)$ & $56(45-60)$ & $48(40-61)$ & 0.127 \\
\hline Lökosit $\left(10^{3} / \mu \mathrm{L}\right)$ & $10.2 \pm 3.4$ & $11.3 \pm 5.1$ & 0.407 \\
\hline Eritrosit sedimantasyon hızı $(\mathrm{mm} / \mathrm{h})$ & $18(10-25)$ & $21(14-35)$ & 0.172 \\
\hline Total kolesterol (mg/dl) & $\begin{array}{l}177 \\
(144-177)\end{array}$ & $\begin{array}{l}198 \\
(169-227)\end{array}$ & 0.038 \\
\hline Düşük dansiteli Kolesterol (mg/dl) & $\begin{array}{l}106 \\
(74-130)\end{array}$ & $124(98-157)$ & 0.025 \\
\hline Yüksek dansiteli Kolesterol (mg/dl) & $29 \pm 10$ & $30 \pm 9$ & 0.818 \\
\hline Trigliserid (mg/dl) & $\begin{array}{l}156 \\
(106-193)\end{array}$ & $\begin{array}{l}140 \\
(106-183)\end{array}$ & 0.430 \\
\hline C-reaktif protein (mg/dL) & $12(6-34)$ & $28(10-67)$ & 0.048 \\
\hline Serbest testosteron (pg/ml) & $10(4-16)$ & $8(4-12)$ & 0.011 \\
\hline Total testosteron (nm/l) & $32 \pm 23$ & $23 \pm 17$ & 0.032 \\
\hline Syntax skoru & $16(10-21)$ & $27(13-39)$ & 0.001 \\
\hline
\end{tabular}

Grup 1 (Syntax skoru <22 olanlar, hafif koroner arter hastalığı); Grup 2 (Syntax skoru $\geq 22$ olanlar, ciddi koroner arter hastalığı ); EF; ejeksiyon fraksiyon.

Tablo 2. Syntax skoru ile laboratuvar parametreleri arasındaki korelasyon analizi

\begin{tabular}{lll}
\hline Değişkenler & $\mathbf{r}$ & $\mathbf{p}$ \\
\hline Total testosteron & -0.480 & 0.001 \\
Serbest testosteron & -0.733 & 0.001 \\
Total kolesterol & 0.239 & 0.018 \\
Düşük dansiteli lipoprotein & 0.286 & 0.004 \\
\hline
\end{tabular}

Tablo 3. Syntax skorunun bağımsız öngördürücülüğünü gösteren çok değişkenli lojistik regresyon analizi

\begin{tabular}{lll}
\hline Değişkenler & OR (\% 95 güven aralığı) & $\mathbf{p}$ \\
\hline Yaş & $0.980(0.936-1.025)$ & 0.374 \\
VKï & $0.998(0.884-1.109)$ & 0.865 \\
DM & $1.628(0.517-5.123)$ & 0.547 \\
HT & $0.511(0.205-1.273)$ & 0.149 \\
Sigara & $1.830(0.628-5.338)$ & 0.275 \\
TK & $1.002(0.982-1.022)$ & 0.869 \\
LDL & $0.990(0.979-1.002)$ & 0.100 \\
CRP & $1.005(0.997-1.013)$ & 0.239 \\
Total testosteron & $0.929(0.700-1.232)$ & 0.608 \\
Serbest testosteron & $0.906(0.838-0.980)$ & 0.014 \\
\hline VKI: Vücut kitle indeksi, HT: Hipertansiyon, DM: Diyabetes mellitus, TK: Total
\end{tabular}

kolesterol, LDL: Düşük dansiteli kolesterol, CRP: C-reaktif protein,

Ciddi KAH'ın (yüksek SS'nin) bağımsız öngördürücülerini tespit etmek amacıyla çok değişkenli lojistik regresyon analizi uygulandı. Yapılan bu analiz sonucunda, serbest testosteron (odds oranı: 0.906; \% 95 güven aralığı: 0.838$0.980, P=0.014$ ) ciddi KAH varlığının bağımsız bir öngördürücüsü olarak tespit edildi (Tablo 3).

\section{Tartışma}

Bu çalışmada ateroskleroza aracilık eden bir hormon olan serbest testesteron ile ciddi KAH varlığı arasındaki ilişkinin incelenmesi amaçlandı. Çalışmamızın ana bulgusu, NSTEMI ile başvuran erkek hastalarda serbest testosteron düzeyinin ciddi $\mathrm{KAH}$ ile bağımsız bir şekilde ilişkili olduğunun tespit edilmiş olmasıdır. Çalışmamızdan elde edilen bulgular, düşük serbest testosteron düzeyi ile aterosklerozis ciddiyeti arasında olası bir ilişki olabileceğini düşündürmektedir.

Koroner anjiyografi, KAH ciddiyetini belirlemede altın standart tanı yöntemi olarak kullanılmaktadır (10). Bu nedenle anjiyografik görüntülemeye dayalı bazı skorlama sistemleri geliştirilmiştir. SS, KAH'nın ciddiyeti ve yaygınlığını belirlemede anjiyografik olarak kullanılan bir skorlama sistemidir. Bu skorlama sisteminde; lezyon sayısı, lezyonun yerleşimi ve fonksiyonel önemi gibi özellikler kullanılmaktadır $(8,9)$. Yapılan çalışmalarda, yüksek SS ile kötü kardiyak olaylar arasında bir ilişki olduğu gösterilmiştir (11). Bu nedenle, bu skorlama sistemi KAH hastalarında yaygın olarak kullanılan bağımsız bir prognostik belirteç olarak kabul edilmektedir.
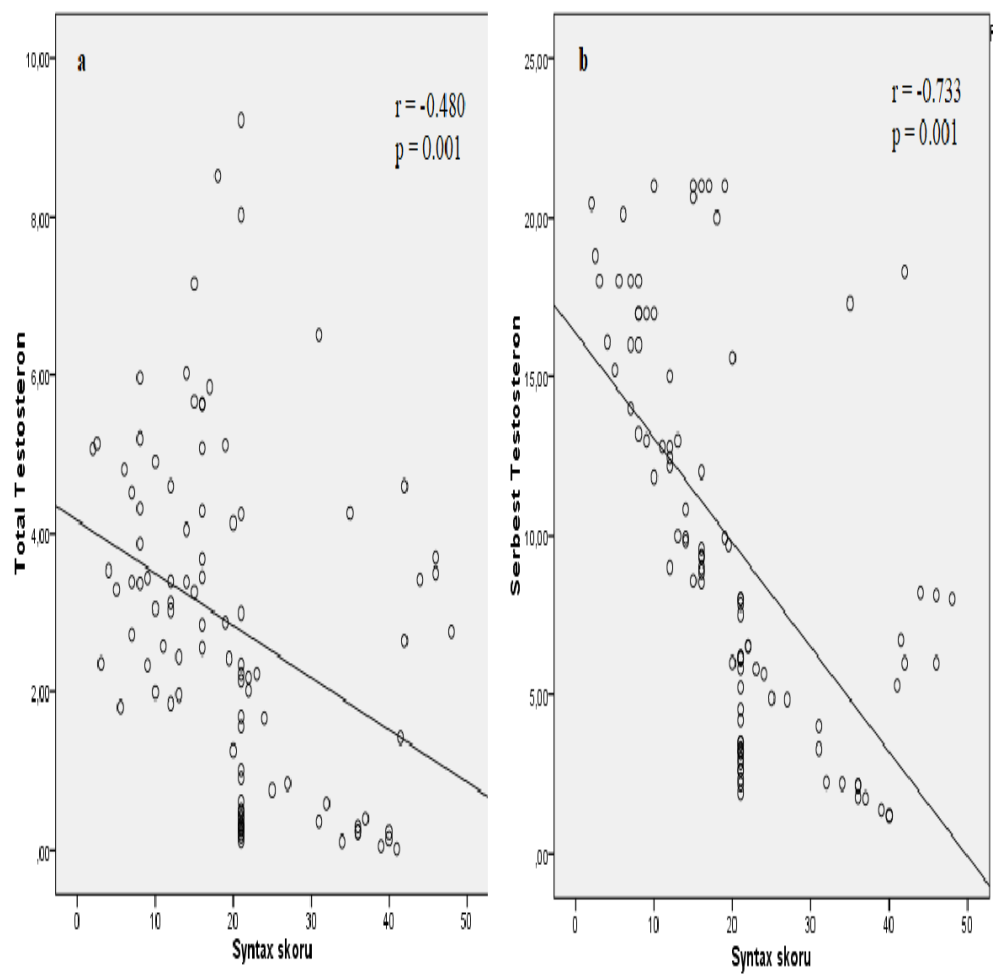

Şekil 1. Syntax skoru ile a) total testosteron ve b) serbest testosteron arasında korelasyon analizi

Ateroskleroz; endotel disfonksiyonu, vasküler inflamasyon ve subintimal lipit birikimi ile karakterize arterlerin karmaşık bir hastalığıdır. Altta yatan mekanizmalar tartışmalı olmasına rağmen, birçok kardiyometabolik risk faktörü ateroskleroz gelişimini kolaylaştırır. Hastalık ilerledikçe aterosklerotik bir plak oluşumu, plak erozyonu veya rüptüründen sonra trombosit aktivasyonu ve trombüs oluşumu ile sonuçlanan akut koroner sendrom gelişmesine sebep olmaktadır (12). Testosteron normal sağlıklı vasküler fonksiyon için gereklidir. Yapılan çalışmalar, testosteronun kardiyo- 
vasküler sistem üzerinde koruyucu etkisinin olduğunu gösterilmiştir.

Testosteronun koruyucu etkisini ilişkilendiren olası mekanizmalar aşağıdaki gibi açıklanmıştır. Illk olarak testosteron interlökin 6, interlökin 1 beta ve tümör nekroz faktör alfa gibi pro-enflamatuar sitokinlerin insan endotel hücrelerinde üretimini inhibe eder (13). İkincisi testosteron yüksek dansiteli lipoprotenin temel bileşeni olan apolipoprotein A1'in hepatik üretimini artırarak yüksek dansiteli lipoproten seviyesini yükseltir (14). Üçüncüsü damar düz kas hücrelerinde potasyum kanal açılmasını ve / veya kalsiyumu kanalının inaktivasyonu ve endotel hücrelerinden nitrik oksid salınımının artıması ile vazodilatatör etki göstermektedir (15). Dördüncüsü dolaşımdaki testosteron seviyesinin, doğrudan aterosklerozda yer alan hemostaz sisteminin ana bileşenlerinden biri olan trombosit agregasyonunu inhibe ettiği bildirimiştir (16). Son olarak düşük testosteron seviyeleri abdominal obezite ile ilişkilidir, bu da aromataz aktivitesinin artmasına neden olur ve bu nedenle daha fazla testosteron östradiole dönüştürülür. Aromataz aktivitesinin artması testosteron seviyelerini daha da azaltır, visseral yağ dokusu birikimini arttıır ve insülin direncinin gelişimine sebep olabilir (17). Yukarıdaki kanıtlar düşük testosteron düzeyinin ateroskleroz patogenezi ile ilişkili olduğunu göstermektedir

Ek olarak, düşük testosteron düzeyine sahip hastaların endotel fonksiyonlarında bozulma meydana geldiği gösterilmiştir (18). Bozulmuş endotel hipotezi aterogenez için temel risk faktörü olduğundan dolayı, düşük testosteron düzeyinin ateroskleroz sürecinde etkili olduğu söylenebilir. Daha önce yapılan çalışmalarda, testosteron replasman tedavisinin iskemi semptomlarını iyileştirdiği ve düşük testosteron düzeyinin istenmeyen kardiyak olaylar ile ilişkili olduğu gösterilmiştir (15). Bununla beraber, yine bir çok çaIışma inflamasyon belirteçleri ile KAH arasındaki ilişkiyi ortaya koymuştur $(12,19,20)$. Çalışmamızda da literatür ile uyumlu olarak daha ciddi KAH bulunan $(S S \geq 22$ ) NSTEMI'li erkek hastalarda, inflamatuvar belirteçlerden olan CRP düzeyinin anlamlı olarak daha yüksek olduğunu tespit ettik. Ek olarak, SS yüksek olan hastalarda serbest testosteron düzeyinin de anlamlı olarak daha düşük olduğunu saptadık. Dahası, SS ile serbest testosteron düzeyi arasında negatif yönde ve güçlü bir korelasyon olduğunu tespit ettik. Ayrıca, SS'nu etkiyebilecek geleneksel risk faktörlerini dâhil ettiğimiz çok değişkenli lojistik regresyon analizinde, serbest testosteronun yüksek SS'nu öngördüren tek bağımsız belirleyicisi olduğunu bulduk. Bu bulgular, NSTEMI hastalarında düšük serbest testosteronun KAH ciddiyetini öngördürmede klinik öneme sahip olduğunu düşündürmektedir. Dolayısıyla başvuru anında düşük serbest testosteron düzeyine sahip olan NSTEMl'li erkek hastalarda KAH yaygınlığının ve ciddiyetinin daha fazla olduğu sonucuna varılabilir.
Çalışmamızın en önemli kısıtlılığı, kesitsel bir çalışma olması ve hasta sayısının az olmasıdır. Bulgularımızın doğrulanması için ileriye yönelik daha geniş popülasyonlu çaIışmalara intiyaç olduğunu düşünmekteyiz. İkinci olarak, çalışmamıza sadece erkek hastalar dâhil edilmiştir ve normal koroner arterleri olan bir kontrol grubu da mevcut değildi. Son olarak, çalışmamızda Syntax 2 skorunun da kullanılması çalışmaya ek katkı sağlayabilirdi. Serbest testosteron ve SS arasındaki ilişkiyi daha iyi aydınlatabilmek için, geniş çaplı ve uzun takiplerin yapıldığı prospektif çalışmalara intiyaç vardır.

Sonuç olarak, ST yükselmesi olmayan miyokart enfarktüsü geçiren erkek hastalarda düşük serbest testosteron düzeyi bağımsız olarak yüksek SS ile ilişkilidir.

Etik Onam: Çalışma için Harran Üniversitesi Tıp Fakültesi Etik Kurulu'ndan etik kurul onayı alındı (Etik kurul tarih: 09/09/2019; karar no: 19/10/12).

\section{Kaynaklar}

1. Sharma K, Gulati M. Coronary artery disease in women: a 2013 update. Glob Heart. 2013;8(2): 105-12.

2. Moolman JA. Unravelling the cardioprotective mechanism of action of estrogens. Cardiovasc Res. 2006;69(4): 777-80.

3. Iorga A, Cunningham CM, Moazeni S, Ruffenach G, Umar S, Eghbali $M$. The protective role of estrogen and estrogen receptors in cardiovascular disease and the controversial use of estrogen therapy. Biol Sex Differ. 2017;8(1): 33.

4. Qing XR, Shang XJ, Huang YF. Testosterone deficiency: an independent risk factor of cardiovascular disease. Zhonghua Nan Ke Xue. 2013;19(8): 742-7.

5. Jones TH. Testosterone deficiency: a risk factor for cardiovascular disease? Trends in Endocrinology and Metabolism 2010;21(8): 496503.

6. Bianchi, Vittorio Emanuele. The anti-inflammatory effects of testosterone. Journal of the Endocrine Society. 2018;3(1): 91-107.

7. Mendel CM. The free hormone hypothesis: a physiologically based mathematical model. Endocr Rev 1989;10(3): 232-74.

8. Sianos G, Morel MA, Kappetein AP, Morice MC, Colombo A, Dawkins $\mathrm{K}$, et al. The SYNTAX Score: an angiographic tool grading the complexity of coronary artery disease. Eurolntervention. 2005; 1(2): 219-27

9. Bundhun PK, Sookharee Y, Bholee A, Huang F. Application of the SYNTAX score in interventional cardiology: A systematic review and meta-analysis. Medicine (Baltimore). 2017; 96(28): 7410

10. Nakamura M. Angiography is the gold standard and objective evidence of myocardial ischemia is mandatory if lesion severity is questionable. - Indication of $\mathrm{PCl}$ for angiographically significant coronary artery stenosis without objective evidence of myocardial ischemia (Pro)-. Circ J. 2011;75(1): 204-10.

11. Safarian $H$, Alidoosti $M$, Shafiee $A$, Salarifar M, Poorhosseini $H, N e-$ matipour $E$. The SYNTAX score can predict major adverse cardiac events following percutaneous coronary intervention. Heart views. 2014;15(4): 99-105.

12. Singh RB, Mengi SA, Xu YJ, Arneja AS, Dhalla NS. Pathogenesis of atherosclerosis: A multifactorial process. Exp Clin Cardiol. 2002; 7(1): 40-53.

13. Hatakeyama $H$, Nishizawa $M$, Nakagawa $A$, Nakano $S$, Kigoshi T, Uchida K. Testosterone inhibits tumor necrosis factor-alpha-induced vascular cell adhesion molecule-1 expression in human aortic endothelial cells. FEBS Lett. 2002;530(1-3):129-32.

14. Kim C, Kong S, Krauss RM, Stanczyk FZ, Reddy ST, Needham BL, 
et al. Endogenous Sex Steroid Hormones, Lipid Subfractions, and Ectopic Adiposity in Asian Indians. Metab Syndr Relat Disord. 2015;13(10): 445-52.

15. Kelly DM, Jones TH. Testosterone: a vascular hormone in health and disease. J Endocrinol. 2013;217(3): 47-71.

16. Karolczak K, Konieczna L, Kostka T, Witas PJ, Soltysik B, Baczek $\mathrm{T}$, et al. Testosterone and dihydrotestosterone reduce platelet activation and reactivity in older men and women. Aging (Albany NY). 2018;10(5): 902-29.

17. Cohen PG. Aromatase, adiposity, aging and disease. The hypogonadal-metabolic-atherogenic-disease and aging connection. Med Hypotheses. 2001;56(6): 702-8.

18. Aminuddin A, Salamt N, Ahmad Fuad AF, Chin KY, Ugusman A, Soelaiman IN, et al. Vascular Dysfunction among Malaysian Men with Increased BMI: An Indication of Synergistic Effect of Free Testosterone and Inflammation. Medicina (Kaunas). 2019; 55(9). pii: E575.

19. Tascanov MB, Tanriverdi Z, Gungoren F, Besli F, Erkus ME, Gonel A, et al. Association between the No-Reflow Phenomenon and Soluble CD40 Ligand Level in Patients with Acute ST-Segment Elevation Myocardial Infarction. Medicina (Kaunas). 2019; 55(7). pii: E376.

20. Taşcanov MB, Güngören F. Akut Koroner Sendromlu Hastalarda Plazma von Willebrand Faktör Düzeyi ile Koroner Arter Hastalığı Ciddiyeti Arasındaki İlişkisi. Harran Üniversitesi Tıp Fakültesi Dergisi. 2019; 16(3): 421-5. 